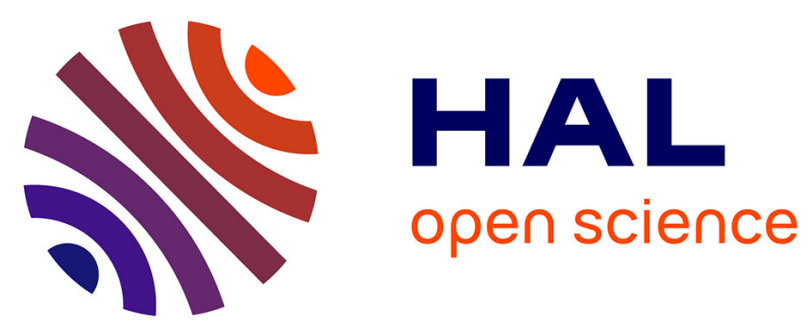

\title{
Diode-pumped regenerative Yb:SrF2 amplifier
}

Sandrine Ricaud, Patrick Georges, Patrice Camy, Jean-Louis Doualan,

Richard Moncorgé, Antoine Courjaud, Eric Mottay, Frédéric Druon

\section{To cite this version:}

Sandrine Ricaud, Patrick Georges, Patrice Camy, Jean-Louis Doualan, Richard Moncorgé, et al.. Diode-pumped regenerative Yb:SrF2 amplifier. Applied Physics B - Laser and Optics, 2012, 106 (4), pp.823-827. 10.1007/s00340-011-4783-x . hal-00657866

\section{HAL Id: hal-00657866 \\ https://hal-iogs.archives-ouvertes.fr/hal-00657866}

Submitted on 9 Jan 2012

HAL is a multi-disciplinary open access archive for the deposit and dissemination of scientific research documents, whether they are published or not. The documents may come from teaching and research institutions in France or abroad, or from public or private research centers.
L'archive ouverte pluridisciplinaire HAL, est destinée au dépôt et à la diffusion de documents scientifiques de niveau recherche, publiés ou non, émanant des établissements d'enseignement et de recherche français ou étrangers, des laboratoires publics ou privés. 


\title{
Diode-pumped regenerative $\mathrm{Yb}: \mathrm{SrF}_{2}$ amplifier
}

\author{
Sandrine Ricaud ${ }^{1,3, *}$, Patrick Georges ${ }^{1}$, Patrice Camy ${ }^{2}$, Jean-Louis Doualan ${ }^{2}$, Richard \\ Moncorgé $^{2}$, Antoine Courjaud ${ }^{3}$, Eric Mottay ${ }^{3}$ and Frédéric Druon ${ }^{1}$ \\ ${ }^{1}$ Laboratoire Charles Fabry de l'Institut d'Optique (LCFIO), UMR 8501 CNRS, Université Paris-Sud, \\ RD 128 Campus Polytechnique, 91127 Palaiseau, France \\ ${ }^{2}$ Centre de recherche sur les Ions, les Matériaux et la Photonique (CIMAP), \\ UMR 6252 CEA CNRS-ENSICaen, Université de Caen, 14050 Caen, France \\ ${ }^{3}$ Amplitude Systèmes, 6 Allée du Doyen Georges Brus, 33600 Pessac, France \\ *sandrine.ricaud@institutoptique.fr
}

\begin{abstract}
We report what we believe to be the first $\mathrm{Yb}: \mathrm{SrF}_{2}$ regenerative femtosecond amplifier. The regenerative amplifier produces 325 -fs pulses at $100-\mathrm{Hz}$ repetition rate with an energy before compression of $1.4 \mathrm{~mJ}$. The interest of $\mathrm{Yb}: \mathrm{SrF}_{2}$ in such regenerative amplifiers and its complementarity to its well-known isotype $\mathrm{Yb}: \mathrm{CaF}_{2}$ is also discussed.
\end{abstract}

(C)2011 Optical Society of America

OCIS codes: (140.3280) Laser amplifiers; (140.3380) Laser materials; (140.3480) Lasers, diode-pumped; (140.3615) Lasers, ytterbium; (320.7090) Ultrafast lasers.

\section{References and links}

1. M. Grishin, V. Gulbinas, A. Michailovas, "Dynamics of high repetition rate regenerative amplifiers," Opt. Express 15, 9434-9443 (2007).

2. P. Camy, J.L. Doualan, A. Benayad, M. von Edlinger, V. Ménard and R. Moncorgé, "Comparative spectroscopic and laser properties of $\mathrm{Yb}^{3+}$-doped $\mathrm{CaF}_{2}, \mathrm{SrF}_{2}$ and $\mathrm{BaF}_{2}$ single crystals," Appl. Phys. B 89(4), 539-542 (2007).

3. J.L. Doualan, P. Camy, A. Benayad, V. Ménard, R. Moncorgé, J. Boudeile, F. Druon, F. Balembois and P. Georges, "Yb ${ }^{3+}$ Doped $(\mathrm{Ca}, \mathrm{Sr}, \mathrm{Ba}) \mathrm{F}_{2}$ for High Power Laser Applications," Laser Physics 20(2), 533-536 (2010).

4. C. R. A. Catlow, A. V. Chadwick, G. N. Greaves, and L. M. Moroney, "Direct observations of the dopant environment in fluorites using EXAFS," Nature 312, 601-604 (1984).

5. M. Siebold, S. Bock, U. Schramm, B. Xu, J. L. Doualan, P. Camy, and R. Moncorgé, "Yb:CaF 2 - a new old laser crystal,” Appl. Phys. B 97(2), 327-338 (2009).

6. V. Petit, P. Camy, J.-L. Doualan, X. Portier, and R. Moncorgé, "Spectroscopy of $\mathrm{Yb}^{3+}: \mathrm{CaF}_{2}$ : From isolated centers to clusters" Phys. Rev. B 78, 085131 (2008).

7. M. Siebold, M. Hornung, R. Boedefeld, S. Podleska, S. Klingebiel, C. Wandt, F. Krausz, S. Karsch, R. Uecker, A. Jochmann, J. Hein, and M. C. Kaluza, "Terawatt diode-pumped Yb:CaF 2 laser," Opt. Lett. 33(23), 2770-2772 (2008).

8. S. Ricaud, F. Druon, D. N. Papadopoulos, P. Camy, J.-L. Doualan, R. Moncorgé, M. Delaigue, Y. Zaouter, A. Courjaud, P. Georges, and E. Mottay, "Short-pulse and high-repetition-rate diode-pumped Yb:CaF regenerative amplifier," Opt. Lett. 35, 2415-2417 (2010).

9. A. Pugžlys, G. Andriukaitis, D. Sidorov, A. Irshad, A. Baltuška, W. J. Lai, P. B. Phua, L. Su, J. Xu, H. Li, R. Li, S. Ališauskas, A. Marcinkevicius, M. E. Fermann, L. Giniunas, and R. Danielius, "Spectroscopy and lasing of cryogenically cooled $\mathrm{Yb}, \mathrm{Na}: \mathrm{CaF}_{2}$," Appl. Phys. B 97, 339-350 (2009).

10. G. Andriukaitis, D. Kartashov, D. Lorenc, A. Pugžlys, A. Baltuška, L. Giniunas, R. Danielius, and J. Limpert "Pulse Compression of $6 \mathrm{~mJ}, 200$-fs Pulses from a cw-Diode-Pumped Single-Stage $\mathrm{Yb}: \mathrm{CaF}_{2}$ MOPA in a Hollow Fiber" in High-Intensity Lasers and High-Field Phenomena, (Optical Society of America, 2011), paper HWA5.

11. M. Siebold, J. Hein, M. C. Kaluza, and R. Uecker, "High-peak-power tunable laser operation of $\mathrm{Yb}: \mathrm{SrF}_{2}$," Opt.Lett. 32, 1818-1020 (2007).

12. T. T. Basiev, M. E. Doroshenko, P. P. Fedorov, V. A. Konyushkin, S. V. Kuznetsov, V. V. Osiko, and M. Sh. Akchurin, "Efficient laser based on $\mathrm{CaF}_{2}-\mathrm{SrF}_{2}-\mathrm{YbF}_{3}$ nanoceramics," Opt. Lett. 33, 521-523 (2008).

13. J. Šulc, H. Jelínková, M. E. Doroshenko, T. T. Basiev, V. A. Konyushkin, and P. P. Fedorov, "Tunability of Lasers Based on $\mathrm{Yb}^{3+}$-Doped Fluorides $\mathrm{SrF}_{2}, \mathrm{SrF}_{2}-\mathrm{CaF}_{2}, \mathrm{SrF}_{2}-\mathrm{BaF}_{2}$, and $\mathrm{YLF}$," in Advanced Solid-State Photonics, OSA Technical Digest Series (CD) (Optical Society of America, 2009), paper WB16.

14. O. K. Alimov, T. T. Basiev, M. E. Doroshenko, P. P. Fedorov, V. A. Konyushkin, S. V. Kouznetsov, A. N. Nakladov, V. V. Osiko, H. Jelinkova, and J. Šulc, "Spectroscopic and Oscillation Properties of $\mathrm{Yb}^{3+}$ ions in 
$\mathrm{BaF}_{2}-\mathrm{SrF}_{2}-\mathrm{CaF}_{2}$ Crystals and Ceramics," in Advanced Solid-State Photonics, OSA Technical Digest Series (CD) (Optical Society of America, 2009), paper WB25.

15. P. Aubry, A. Bensalah, P. Gredin, G. Patriarche, D. Vivien, and M. Mortier, "Synthesis and optical characterizations of Yb-doped CaF2 ceramics," Opt. Mater., 31 (2009) 750-753.

16. F. Friebel, F. Druon, J. Boudeile, D. N. Papadopoulos, M. Hanna, P. Georges, P. Camy, J. L. Doualan, A. Benayad, R. Moncorgé, C. Cassagne, and G. Boudebs, "Diode-pumped 99 fs $\mathrm{Yb}: \mathrm{CaF}_{2}$ oscillator," Opt. Lett. 34(9), 1474-1476 (2009).

17. F. Druon, D. N. Papadopoulos, J. Boudeile, M. Hanna, P. Georges, A. Benayad, P. Camy, J. L. Doualan, V Ménard, and R. Moncorgé, "Mode-locked operation of a diode-pumped femtosecond $\mathrm{Yb}: \mathrm{SrF}_{2}$ laser," Opt. Lett. 34, 2354-2356 (2009).

18. J. Boudeile, J. Didierjean, P. Camy, J. L. Doualan, A. Benayad, V. Ménard, R. Moncorgé, F. Druon, F. Balembois, and P. Georges, "Thermal behaviour of ytterbium-doped fluorite crystals under high power pumping," Opt. Express 16, 10098-10109 (2008).

19. D. N. Papadopoulos, F. Druon, J. Boudeile, I. Martial, M. Hanna, P. Georges, P. O. Petit, P. Goldner, and B. Viana, "Low-repetition-rate femtosecond operation in extended-cavity mode-locked Yb:CALGO laser," Opt. Lett. 34, 196-198 (2009).

20. http://cmdo.cnrs.fr/ and http://www.lasur-femto.cnrs.fr/

\section{Introduction}

The rising demand for efficient micro-processing laser sources has led to the development of high repetition rate ultra-short pulse solid-state lasers. Regenerative amplifiers permit amplification of ultra-short pulses with a gain of several orders of magnitude [1]. However, gain narrowing limits the pulse duration after amplification so that crystals with broad gain spectrum are needed to obtain really short pulses. Furthermore, an energy level around $1 \mathrm{~mJ}$ is required, which implies that materials with long fluorescence lifetimes should be used.

Spectroscopic and thermal properties of ytterbium-doped $(\mathrm{Ca}, \mathrm{Ba}, \mathrm{Sr}) \mathrm{F}_{2}$ laser crystals make them ideal candidates for high power laser applications [2,3]. Their crystallographic properties are well-known [4]. Specifically, there has been a recent renewed interest in $\mathrm{Yb}: \mathrm{CaF}_{2}$ [5]. Indeed, its high thermal conductivity, $9.7 \mathrm{~W} \cdot \mathrm{m}^{-1} \cdot \mathrm{K}^{-1}$ for an undoped crystal, its broad and smooth emission and absorption cross sections, owing to the particular $\mathrm{Yb}^{3+}$ cluster responsible for the lasing properties inside the doped crystal $[4,6]$, and its long fluorescence lifetime $(2.4 \mathrm{~ms})$, enable the generation of energetic laser pulses at different repetition rates. Based on $\mathrm{Yb}: \mathrm{CaF}_{2}$, a terawatt system already generated 197-mJ, 192-fs pulses at a repetition rate of $1 \mathrm{~Hz}$ [7], and a regenerative amplifier system was used to generate $0.8-\mathrm{mJ}, 178 \mathrm{-fs}$ pulses at a $500 \mathrm{~Hz}$ repetition rate [8]. Furthermore, at cryogenic temperature, a co-doped $\mathrm{Yb}^{3+}, \mathrm{Na}^{+}: \mathrm{CaF}_{2}$ amplifier [9] has delivered $173-\mathrm{fs}, 2.5-\mathrm{mJ}$ pulses at a $1 \mathrm{kHz}$ repetition rate and a $\mathrm{Yb}^{3+}: \mathrm{CaF}_{2}$ amplifier has already produced $200-\mathrm{fs}, 6-\mathrm{mJ}$ pulses at $500 \mathrm{~Hz}$ repetition rate [10].

At room temperature the spectroscopic characteristics of $\mathrm{Yb}: \mathrm{CaF}_{2}$ and $\mathrm{Yb}: \mathrm{SrF}_{2}$ are very similar. However, each of them has its own advantages, a higher peak absorption cross section around $980 \mathrm{~nm}$ and a longer fluorescence lifetime (2.9 ms) for $\mathrm{Yb}: \mathrm{SrF}_{2}[2,11]$, and a wider and larger gain cross section spectrum for $\mathrm{Yb}: \mathrm{CaF}_{2}$ [2]. In a regenerative amplifier configuration, the longer fluorescence lifetime is crucial since it permits higher energy storage, which leads potentially to higher energy pulses with repetition rates in the $100 \mathrm{~Hz}$ range. We also notice that the $\mathrm{Yb}: \mathrm{SrF}_{2}$ gain cross section spectrum is shifted to shorter wavelengths in comparison to the $\mathrm{Yb}: \mathrm{CaF}_{2}$ one. This is interesting for addressing different wavelengths.

Moreover, reference [2] indicates that crystal growth seems to lead to comparable optical qualities. Indeed for a $2.6 \% \mathrm{Yb}$-doped $\mathrm{CaF}_{2}$ and a $2.9 \% \mathrm{Yb}$-doped $\mathrm{SrF}_{2}$, the authors measured about the same laser threshold, the same slope efficiency and the same wavelength tunability. Furthermore, because of the simple cubic structure of these materials, high optical quality ceramics can be prepared [12-15]. Indeed, laser oscillations under diode pumping have been 
recently obtained with slope efficiencies not far from those obtained with single crystals of similar compositions [12-14].

Finally, these very close properties have also permitted to obtain, with single crystals, relatively similar results in femtosecond operation. Ultra-short mode-locked oscillators have been demonstrated, with a pulse duration of $99 \mathrm{fs}$ and an average output power of $380 \mathrm{~mW}$ for $\mathrm{Yb}: \mathrm{CaF}_{2}$ [16], and $143 \mathrm{fs}$ with a power of $450 \mathrm{~mW}$ for $\mathrm{Yb}: \mathrm{SrF}_{2}$ [17]. The pulse duration was shorter with $\mathrm{Yb}: \mathrm{CaF}_{2}$ because of Kerr lens-assisted mode-locking, which was not observed in the case of $\mathrm{Yb}: \mathrm{SrF}_{2}$ because of stability concern probably due to the longer emission lifetime of $\mathrm{Yb}: \mathrm{SrF}_{2}$ compared to $\mathrm{Yb}: \mathrm{CaF}_{2}$.

From the amplification point of view, the longer lifetime of $\mathrm{Yb}: \mathrm{SrF}_{2}$ becomes a strong advantage for energy storage. In fact, the operating regimes addressed by these two crystals in amplifier configuration are not exactly the same: for high average power laser amplification, $\mathrm{Yb}: \mathrm{CaF}_{2}$ shows more interesting thermal properties [18], whereas, from the point of view of energy storage and energy extraction, $\mathrm{Yb}: \mathrm{SrF}_{2}$ seems more appropriate, especially at low repetition rate. It is therefore interesting to investigate the potential of $\mathrm{Yb}: \mathrm{SrF}_{2}$ in a regenerative amplifier and compare the results with its more popular isotype $\mathrm{Yb}: \mathrm{CaF}_{2}$.

For that purpose, we present here a room-temperature diode-pumped $\mathrm{Yb}: \mathrm{SrF}_{2}$ regenerative amplifier, in order to compare the performances of $\mathrm{Yb}: \mathrm{SrF}_{2}$ to $\mathrm{Yb}: \mathrm{CaF}_{2}$ and discuss its potential in short-pulse amplifiers.

\section{Experimental setup}

The experiment is performed with a 4 -mm-long, $2.9 \% \mathrm{Yb}$-doped $\mathrm{SrF}_{2}$ crystal positioned at Brewster angle and mounted on a copper holder inside the cavity. The cavity is presented in fig. 1, and is very similar to the one described in [8], which is essential to allow a good comparison with the $2.6 \% \mathrm{Yb}$-doped $\mathrm{CaF}_{2}$.

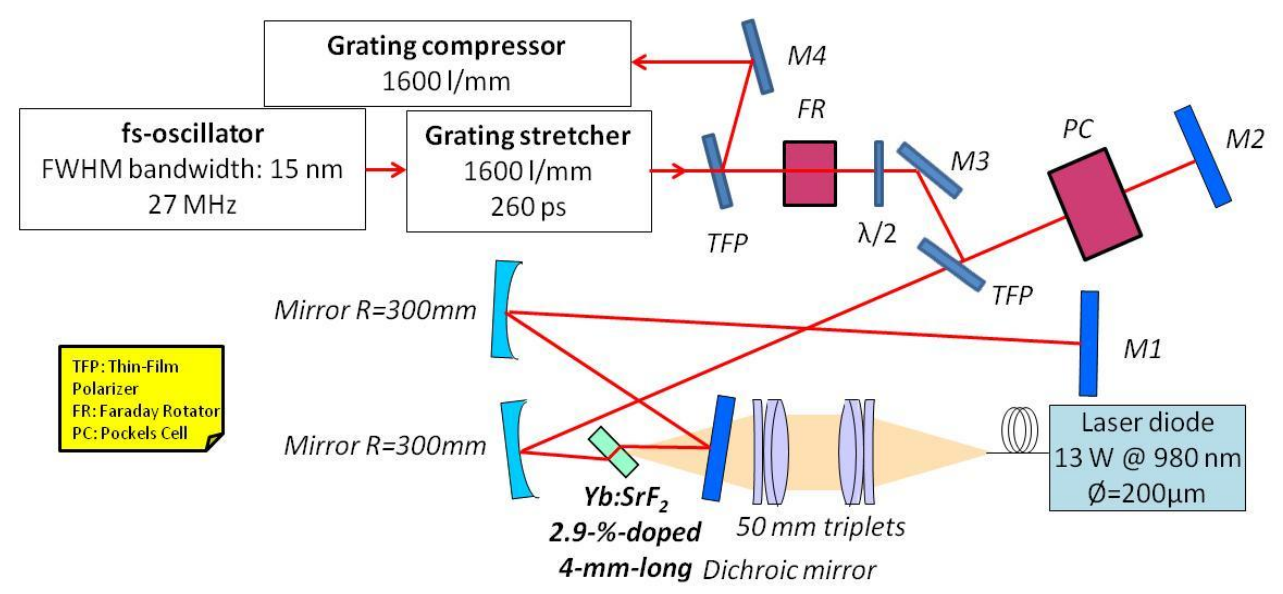

Fig. 1 Experimental setup

The seed pulses are generated by a broadband Yb:CALGO oscillator, at a repetition rate of 27 $\mathrm{MHz}$ [19], with a spectrum of $15 \mathrm{~nm}$ centered at $1043 \mathrm{~nm}$. They are stretched up to $260 \mathrm{ps}$ with a transmission grating $(1600 \mathrm{l} / \mathrm{mm})$. Then, a thin-film polarizer (TFP), a Faraday rotator and a half-wave plate separate the input and the output beam of the regenerative amplifier. The regenerative cavity has a length around $1.5 \mathrm{~m}$, contains a TFP and a BBO Pockels cell (PC) for polarization switching, to inject seed pulses from the oscillator and extract amplified pulses. The $\mathrm{PC}$ acts as a quarter-wave plate at $45^{\circ}$ in static regime, and as a half-wave plate with high voltage. The crystal is longitudinally pumped through a dichroic mirror by a $13 \mathrm{~W}$ fiber-coupled laser diode, emitting at $980 \mathrm{~nm}(200 \mu \mathrm{m}$ core diameter with a NA of 0.22). 
We optimize the overlap between the laser and the pump beams inside the crystal using two $50-\mathrm{mm}$ focal length triplets, resulting in a focal spot of $200 \mu \mathrm{m}$. The chirped pulses are finally compressed with two transmission gratings $(1600 \mathrm{l} / \mathrm{mm})$ with an overall efficiency of $60 \%$.

\section{Results}

The Q-switched regime permits to evaluate the achievable energy, average power and spectrum before regenerative configuration. At a low repetition rate of $100 \mathrm{~Hz}$, we obtain up to $1.4 \mathrm{~mJ}$, and at a high repetition rate of $5 \mathrm{kHz}$, the power is $580 \mathrm{~mW}$. The spectrum presents two peaks (fig. 2) at 1027 and $1040 \mathrm{~nm}$. The peak at $1027 \mathrm{~nm}$ is the highest, so that despite the shift between the oscillator spectrum and the $\mathrm{Yb}: \mathrm{SrF}_{2}$ gain bandwidth, we expect the amplified spectrum to be shifted towards shorter wavelengths. In order to benefit from the entire gain spectrum we use a broad spectral bandwidth oscillator centered at $1040 \mathrm{~nm}$ that exhibits a low but non-negligible spectral intensity at $1027 \mathrm{~nm}$. In this case the lower gain peak at $1040 \mathrm{~nm}$ is seeded with more spectral energy density than the intense peak at 1027 $\mathrm{nm}$ to counterbalance the smaller gain at $1040 \mathrm{~nm}$.

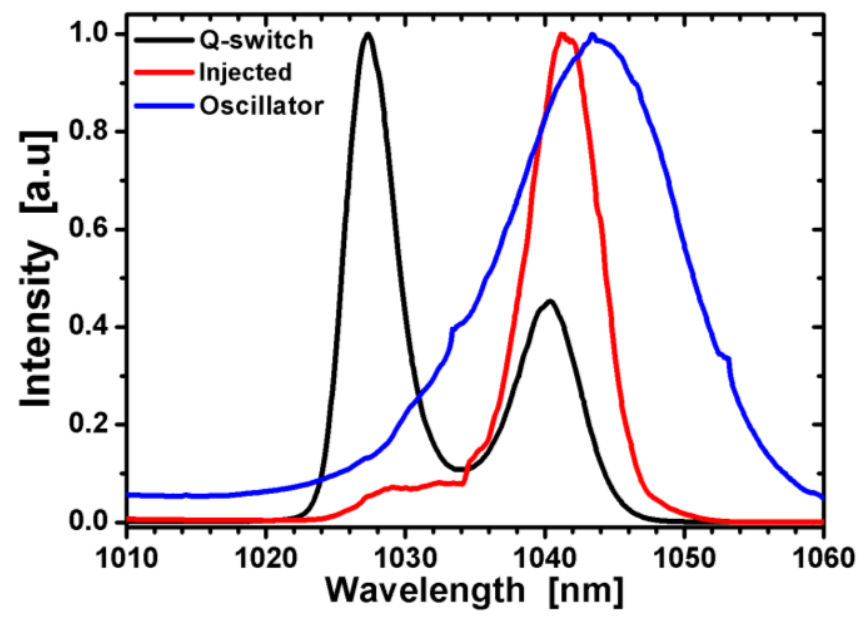

Fig. 2 Evolution of the spectrum in Q-switched and injected regime (black-red), and oscillator spectrum (blue)

The obtained amplified spectrum shown in fig. 2 shows that the wavelength shift between the oscillator and the amplifier gain is too large and does not allow broadband amplification, since only a weak shoulder appears on the short wavelength side of the amplified spectrum. In these conditions, the spectral bandwidth (FWHM) of the amplified pulse is only $5.8 \mathrm{~nm}$ (fig. 2). This leads to a pulse duration of about 330 fs almost independent of the repetition rate. The pulse duration with $\mathrm{Yb}: \mathrm{SrF}_{2}$ is longer than with $\mathrm{Yb}: \mathrm{CaF}_{2}(178 \mathrm{fs})$ because in the latter case it was possible to amplify simultaneously the two peaks located at $1036 \mathrm{~nm}$ and $1047 \mathrm{~nm}$.

With $\mathrm{Yb}: \mathrm{SrF}_{2}$, at $100 \mathrm{~Hz}$ repetition rate, we obtain a pulse duration of $325 \mathrm{fs}$ for a spectral bandwidth of $5.8 \mathrm{~nm}$ (FWHM), as measured with a frequency-resolved optical gating (SHG-FROG) and an autocorrelator (fig. 3). The Fourier transform-limited pulse duration with this measured spectrum is $305 \mathrm{fs}$. The difference comes from a small amount of highorder uncompensated spectral phase as shown on the SHG-FROG phase measurement (fig. 3). The energies before and after compression are $1.4 \mathrm{~mJ}$ and $850 \mu \mathrm{J}$ respectively, which leads to an-optical-to-optical efficiency of $1.1 \%$ before compression. Furthermore, with a pump absorption of $52 \%$, the laser/absorbed pump power efficiency is about $2.1 \%$. We think, this relatively low efficiency is mainly due to a lower gain compared to $\mathrm{Yb}_{2} \mathrm{CaF}_{2}$. The build- 
up time in the present case is $1.7 \mu$ s compared to $1.4 \mu$ s in the case of $\mathrm{Yb}_{\mathrm{CaF}}$. The beam profile has a Gaussian shape, with $\mathrm{M}^{2}<1.1$ both in vertical and horizontal directions.
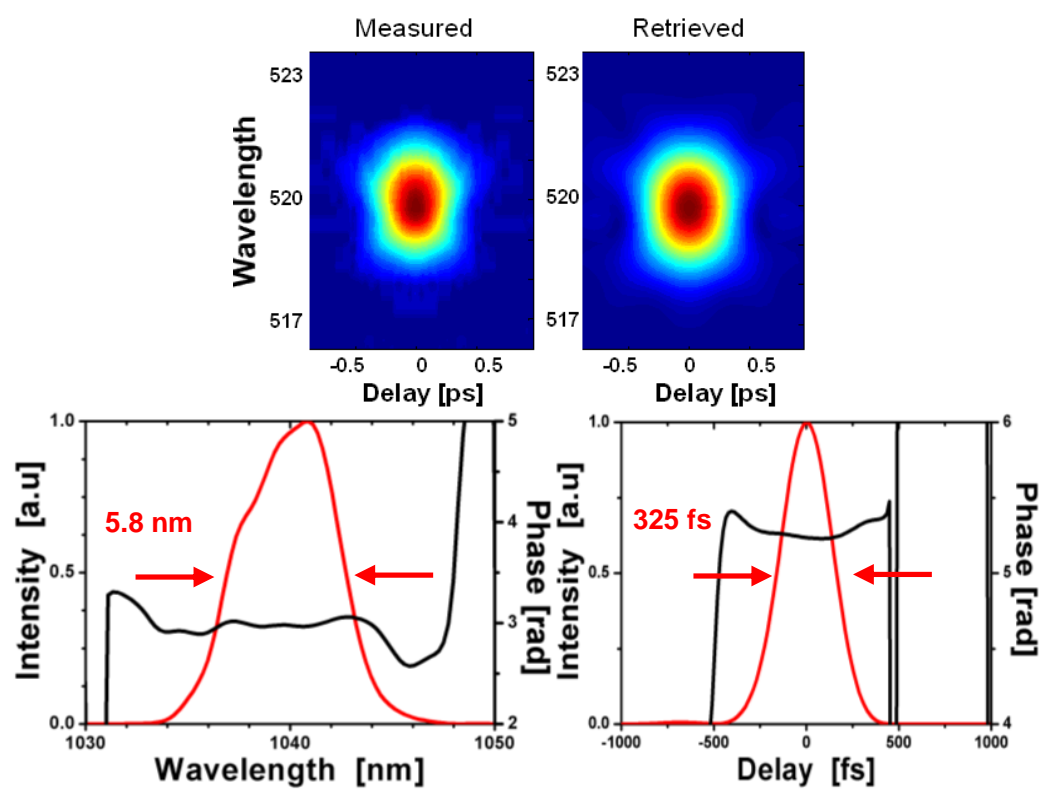

Fig. 3 Recompressed pulse measurement with SHG-FROG at 100-Hz repetition rate

The pulse energy and average output power versus repetition rate are plotted in figure 4 after compression. At high repetition rate, the energy is strongly reduced and the output power reaches $540 \mathrm{~mW}$ before compression and $320 \mathrm{~mW}$ after. In these conditions, the optical-to-optical efficiency is $4.2 \%$ prior to compression, and due to the pump absorption increase to $58 \%$, we obtain a laser/absorbed pump power efficiency of $7.2 \%$.

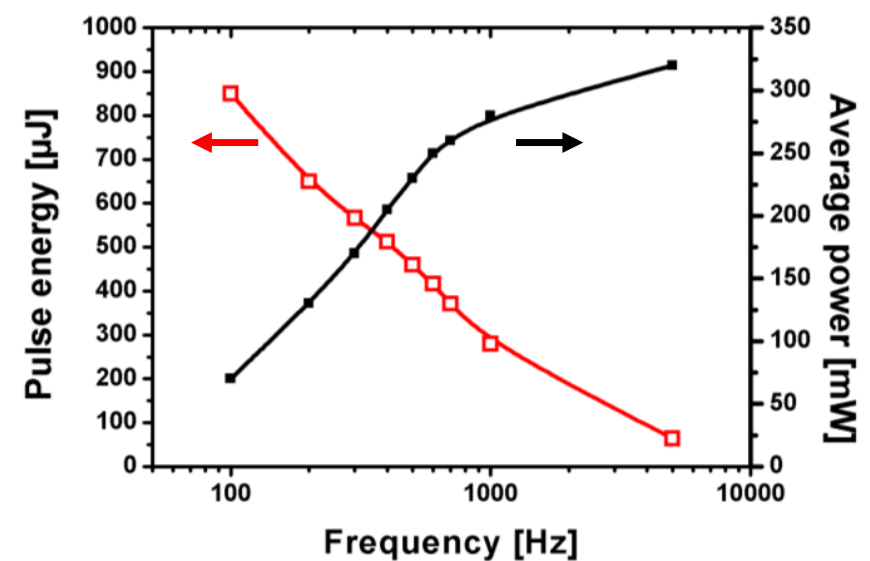

Fig. 4 Evolution of output pulse energy and average power after compression versus repetition rate

\section{Discussion}

We have obtained shorter pulses with an $\mathrm{Yb}: \mathrm{CaF}_{2}$ regenerative amplifier, mainly due to the better overlap between the oscillator and the $\mathrm{Yb}: \mathrm{CaF}_{2}$ gain spectra. Indeed, the $\mathrm{Yb}: \mathrm{SrF}_{2}$ gain spectrum is shifted to shorter wavelengths, and only a part of the spectrum is amplified. The spectrum obtained in the Q-switched regime gives information about the material gain spectrum. In this regime, when we observe (fig. 5) spectra obtained with $\mathrm{Yb}: \mathrm{CaF}_{2}$ and 
$\mathrm{Yb}: \mathrm{SrF}_{2}$, we notice that they are remarkably complementary. In fact, the two spectra have a "camel" shape, with peaks located at 1027 and $1041 \mathrm{~nm}$ and a dip at $1036 \mathrm{~nm}$ for $\mathrm{Yb}: \mathrm{SrF}_{2}$, and peaks at 1036 and $1047 \mathrm{~nm}$ and a dip at $1041 \mathrm{~nm}$ for $\mathrm{Yb}: \mathrm{CaF}_{2}$. Thus, by combining the two materials we should obtain a broadband gain spectrum between 1025 and $1050 \mathrm{~nm}$. Seeded by a broadband oscillator, with a spectrum centered at $1038 \mathrm{~nm}$, a regenerative amplifier with both crystals in the cavity should lead to sub-100fs laser pulses, with the potential for a few millijoules pulses at a high repetition rate.

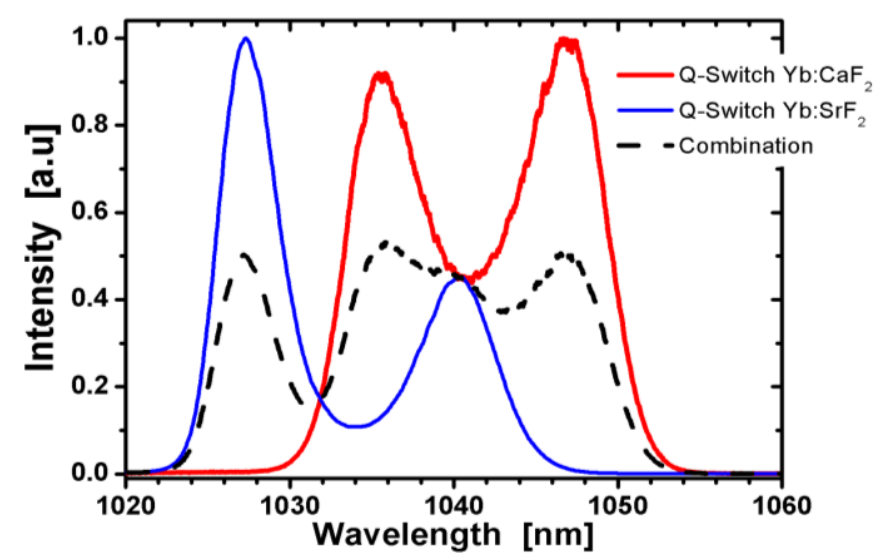

Fig. $5 \mathrm{Yb}: \mathrm{SrF}_{2}$ and $\mathrm{Yb}: \mathrm{CaF}_{2}$ spectra in a Q-switched regime

Another way to obtain this very broad spectrum with both crystals is to combine them into one single mixed $\mathrm{Yb}: \mathrm{Ca}_{\mathrm{x}} \mathrm{Sr}_{1-\mathrm{x}} \mathrm{F}_{2}$ crystal or ceramic [12-14]. As already demonstrated in reference [13], smooth and very broad spectra can be obtained for example with $\mathrm{Yb}: \mathrm{CaF}_{2^{-}}$ $\mathrm{SrF}_{2}$ and $\mathrm{Yb}: \mathrm{SrF}_{2}-\mathrm{BaF}_{2}$ materials.

\section{Conclusion}

We have demonstrated the first diode-pumped $\mathrm{Yb}: \mathrm{SrF}_{2}$ regenerative amplifier at high repetition rate. At a $100 \mathrm{~Hz}$ repetition rate, we obtain 330-fs pulses with an energy of $850 \mu \mathrm{J}$ (after compression). The highest average power achieved at high repetition rate is $540 \mathrm{~mW}$ prior to compression, which corresponds to an optical-to-optical efficiency of $4.2 \%$. These results are interesting despite the fact they are less impressive than with $\mathrm{Yb}: \mathrm{CaF}_{2}$ in the same conditions. Indeed, the gain spectra of these crystals happen to be very complementary, and open an almost flat gain window between $1025 \mathrm{~nm}$ and $1050 \mathrm{~nm}$. Shorter pulses with a high energy at a high repetition rate should be obtained by seeding the amplifier with a broadband oscillator centered at $1034 \mathrm{~nm}$, and by using a combination of $\mathrm{Yb}: \mathrm{CaF}_{2}$ and $\mathrm{Yb}_{\mathrm{SrF}}$ crystals.

\section{Acknowledgments}

This work was supported by the CMDO+ and FEMTO [20] CNRS-MRCT networks through the entitled CRYBLE program, and by the Agence Nationale de la Recherche (ANR) through the entitled FEMTOCRYBLE project. 